\title{
Trends in Body Mass Index among Children with Mild and Moderate Intellectual Disabilities
}

\author{
Jitka Králíková, Hana Válková
}

Faculty of Sports Studies, Masaryk University, Brno

\begin{abstract}
In recent years, worldwide obesity has increased both in the adult as well as childhood populations. Research shows that obesity nowadays is associated with still younger age. What is currently becoming the focal point of attention is the prevalence of obesity in people with intellectual disabilities whose physical and mental limitations affect, to a certain degree, their daily lives. Nevertheless, there is a lack of data for the childhood population with intellectual disabilities.

This research seeks to compare trends in BMI indicators and eating habits among children with mild and moderate intellectual disabilities who live with their families as opposed to those who are provided for at Children's home in region Zlín in the Czech Republic.

The research method used was quantitative and comparative research approached deductively and using correlation. BMI indicators were determined by means of InBody analyser. Eating habits data were collected through a questionnaire of our own design which is standardly used in the Special Olympics Healthy Athlete Project. The BMI trends were observed in twelve children from two primary schools.

We have concluded that children with mild ID who are provided for at the children's home do not tend to be obesity, rather they have a proclivity to overweight or normal BMI and children with moderate ID have a proclivity to normal BMI or underweight. As emerged from case histories, only children with moderate ID living with their own families tend to have obesity or normal BMI but children with mild ID living with their own families tend to have overweight or normal BMI. Obesity and overweight are connected only with boys.

Children's weight remained the same within the existing BMI ranges. Summer holidays in children with mild ID and moderate ID living in children's home had no verifiable effect on the BMI indicators. Children living in their own families had a subsequent weight rise before summer holiday (June 2017, June 2018) and a weight loss after holiday (September 2017, September 2018). Summer holiday influences the BMI indicators in children with mild ID and moderate ID living in their families.

The research further shows that children with mild ID and moderate ID being cared for in the institutional environment have a healthier diet than children with mild ID and moderate ID living with their families.

The direct mean correlation force is between dietary habits and muscles in children with moderate ID living in their family. The indirect mean correlation force is between dietary habits and fat in children with moderate ID living in residential care.

The conclusions of the research may serve as a recommendation for parents to pay more attention to their children's diet as well as their physical activity.
\end{abstract}

Key words: children with intellectual disabilities, mild level of intellectual disability, moderate level of intellectual disability, BMI indicator, obesity, eating habits. 


\section{INTRODUCTION}

Childhood obesity is considered one of the most pressing public health issues of today. Its prevalence is continuously rising. Unfortunately, no consensus as to how this problem should be resolved has been reached yet. Obesity has mostly been regarded as a matter of personal and parental responsibility. The intervention of governments usually lies in laying down normative regulations as to what constitutes a healthy diet and what food should be prepared in schools. (Duramy, 2018). It has been found out that childhood obesity is more prevalent in children who have been exposed to high levels of stress and as a result suffer from behavioural issues, learning difficulties, emotional problems and somatization (Tanu et al., 2018). In the Czech Republic, the number of obese children in primary schools is on the increase. Whilst 20 years ago, only $4 \%$ of children were obese, nowadays the percentage is $14 \%$ for obesity and $25 \%$ for overweigh. The most common factors are a bad lifestyle and poor eating habits (Eurozprávy.cz, 2008).

Intellectual disability (ID) is an umbrella term for congenital handicap of intellectual abilities which are manifested as an inability to understand and adapt to one's surroundings (Vágnerová, 2004, p. 289). Intellectual disability in an individual is seen as a limitation in intellectual functioning and adaptive behaviours (Švarcová, 2000, p. 28). According to Valenta and Müller (2003, p. 10), intellectual disability is a developmental mental disorder manifesting in lower intelligence. It is demonstrated especially as a deficit in cognitive, speech, motor and social abilities. In terms of IQ, intellectual disabilities can be divided into mild (50-69), moderate (35-49), severe (20-34) and profound (below 20) (NICM, 2014).

Individuals with mild ID are comparable with children at the age of 9 to 12 . They can be educated at special needs primary schools. Speech is used functionally in day-to-day situations. Individuals with mild ID are able to hold a conversation and respond in a clinical interview despite the delay in speech development. Most of them manage to master self-care, i.e. eating, getting dressed, hygiene, bladder and bowel control and practical household chores.

Individuals with moderate ID are comparable with children of pre-school age, i. e. 3-6 years old. The development of cognitive and language skills is considerably delayed. Learning occurs solely on the practical level and includes mastering self-care activities and basic skills (Kocourová, 2014). Some pupils are able to attain the grounding in reading, writing and maths under the tutelage of a qualified teacher. Self-care and fine motor skills also develop with delay. Adults with moderate ID are able to carry out simple manual work under supervision. They are not able to live a life completely independent of support and instruction. This degree of disability is characteristic of noticeable differences. Some individuals attain a higher level of sensory motor skills or are capable of social interaction, for example a simple conversation, whilst others are not able to communicate their basic needs (Švarcová, 2000, pp. 28-29).

School-age child development comprises the period of ages between 8 and 11. Children in this age group exhibit a change in physical proportions, i.e. the growth of extremities and trunk as compared to the head which appears to be smaller. Physical form appears more rounded and first adult teeth are beginning to grow. Children are exposed to life-changing events. They start attending school and take part in different social interactions. Further characteristics include cooperation, competition, accepting objective reality at face value and dependence on the leadership of parents and teachers. The development of physical characteristics in children with ID corresponds to that of the general childhood population unless there is a combination with, for instance, Down syndrome, cerebral palsy or organic brain damage.

Puberty is a developmental stage which covers the ages between 12 and 15 and is characteristic of the development of secondary sex characteristics and growth spurt initiated by the production of sex hormones. A child gradually becomes an adult physically as well as mentally. Due to hormonal changes, emotional stability is compromised; there is a heightened sense of anxiety, 
insecurity and low self-esteem. Group identity and first interactions with the opposite sex gain on importance. (Studium Psychologie, 2016).

People with intellectual disabilities have a shorter lifespan and a higher mortality in comparison with the general population (Bittles et al., 2002). This observation is also supported by Patja, Iivanainen, Vesela, Oksanen \& Ruoppila (2000). Conditions such as epilepsy, osteoporosis, motion disorders, obesity, intestinal motility disorders and hyperlipidemia are more often found in people with intellectual disabilities (Tyler, Schramm, Karafa, Tang \& Jain, 2010). According to Havercamp, Scandline \& Roth (2004, pp. 418-426) and Cooper, Melville \& Morrison (2004, pp. 414-415), this population also has a worse state of health and concurrently difficult access to primary healthcare. Consequently, Special Olympics International (SOI) supported The Healthy Community Project, whose project partners between 2016 and 2019 were The Czech Association of Special Olympics and The Faculty of Sports Studies (Válková, 2016); (Válková \& Krejčí, 2016, p. 47).

An increased body weight, which is more common in people with intellectual disabilities, is a significant risk factor for the onset of certain diseases (Melville, Hamilton, Miller \& Boyle, 2007); (Rimmer \& Yamaki, 2006). According to Melville, Hamilton, Miller \& Boyle (2007), the prevalence of obesity is $15-50 \%$ for women and $2-45 \%$ for men (pp. 223-230). The risk of obesity appears to be especially high in women, people with Down syndrome and people with mild ID (Melville, Hamilton, Miller \& Boyle, 2007); (Hsieh, Rimmer \& Heller, 2014). Svačina \& Bretšnajdrová (2003, p. 35) also indicate the significance of gender as a factor in obesity: women tend to be more obese then men in all populations. Other factors include education, in relation to which higher income means a lower BMI, and alcoholism which leads to an increase in weight.

Stancliffe et al. (2011) underscores the need to assess living arrangements during the obesity risk factor analysis (pp. 401-418). People living in institutional environments have the lowest prevalence of obesity and people living in their own homes experience the highest prevalence of obesity (Melville, Hamilton, Miller \& Boyle, 2007); (Stancliffe et al., 2011).

All cited authors reference to the BMI scale of the World Health Organization (WHO). The BMI was developed as a tool for estimating the risk of disease. The higher the BMI, the higher the risk for certain medical conditions. Being overweight or obese means a higher risk of premature death, cardiovascular disease, high blood pressure, arthrosis, certain kinds of cancer and diabetes (WHO, 2018).

The aim of the presented study, which is part of the Special Olympics Healthy Community project (HC-ZAS), is to compare BMI trends and diets in children with mild ID and moderate ID who live in their own home with children living in a children's home in the region of Zlín.

\section{METHODOLOGY}

\section{Participants}

The study participants were pupils of Primary school Otrokovice and the Special Needs and Practical School in Zlín. The criteria for their selection was mild ID and moderate ID and the address of their home. Six children were selected from Otrokovice Primary School who live in their families (three children with mild ID and three children with moderate ID), and six other participants (three children with mild ID and three children with moderate ID), who live in residential care, were chosen from Zlín Special Needs and Practical School. In total, 12 pupils were selected for the BMI trends evaluation, of which 11 have ID with no further impairment, whereas 1 pupil has Down Syndrome. The ages of the participants range between 8 and 15 years, which covers two developmental stages: early school age and puberty (Table 1). The data collection was conducted in four instances throughout the period of 2 years, always in June and September, to find out whether the summer holiday affect BMI indicators. The ethical consensus was guaranteed. 
Tab. 1: The characteristics of participants

\begin{tabular}{|l|c|c|c|c|c|c|c|c|}
\hline \multirow{2}{*}{ Periodization } & \multicolumn{2}{|c|}{$\begin{array}{c}\text { June } \\
2017\end{array}$} & \multicolumn{2}{c|}{$\begin{array}{c}\text { September } \\
2017\end{array}$} & \multicolumn{2}{c|}{$\begin{array}{c}\text { June } \\
2018\end{array}$} & \multicolumn{2}{c|}{$\begin{array}{c}\text { September } \\
2018\end{array}$} \\
\cline { 2 - 11 } & boys & girls & boys & girls & boys & girls & boys & girls \\
\hline Younger school age 8-11 age & 4 & 4 & 4 & 4 & 4 & 2 & 3 & 2 \\
\hline Pubescence 12-15 age & 2 & 2 & 2 & 2 & 2 & 4 & 3 & 4 \\
\hline Total & 6 & 6 & 6 & 6 & 6 & 6 & 6 & 6 \\
\hline
\end{tabular}

\section{Data acquisition and analysis}

The InBody 230 analyser, which provides accurate results of body composition (fat, active body mass and water), was used for the detection of obesity. InBody uses the method of 8-point tactile electrodes which enable to measure the body in segments. The data collection took place in the schools' gym and was carried out within the space of two days at two different schools, one day each. In the picture below (Figure 1), we can see the example of the BMI scanning taken at one of the special needs primary schools. Measurements were always taken in the morning from the youngest to the oldest children.

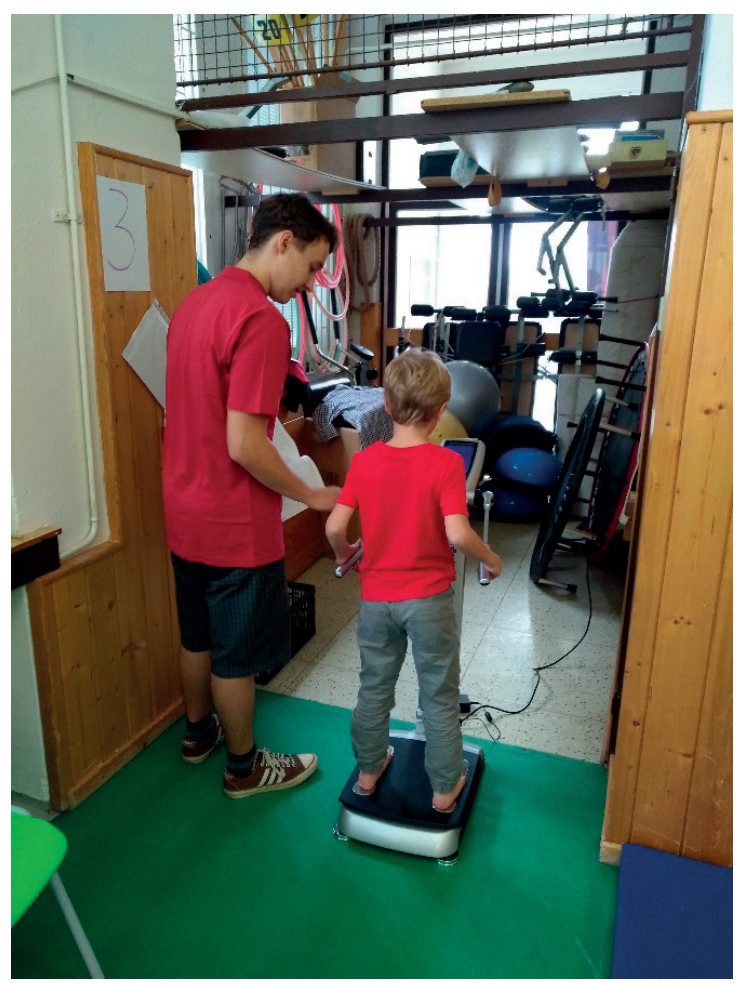

Fig. 1: BMI scanning with InBody230

Detailed analysis of participants using InBody is shown in the table (Table 2). Muscles and fat are given in kilograms. 
Tab. 2: Characteristics of participants in terms of body composition

\begin{tabular}{|c|c|c|c|c|c|c|}
\hline \multicolumn{2}{|c|}{ Participants/Period } & \multirow{2}{*}{\begin{tabular}{l|} 
June \\
2017 \\
15,1 \\
\end{tabular}} & \multirow{2}{*}{\begin{tabular}{|c|}
$\begin{array}{c}\text { September } \\
2017\end{array}$ \\
14,3
\end{tabular}} & \multirow{2}{*}{$\begin{array}{l}\text { June } \\
2018 \\
15,3 \\
\end{array}$} & \multirow{2}{*}{$\begin{array}{c}\text { September } \\
2018 \\
14,7\end{array}$} & \multirow{2}{*}{ Parameter } \\
\hline \multirow{3}{*}{ Girl 11-12 age } & BMI & & & & & \\
\hline & Muscles & 13,5 & 14,4 & 15,6 & 19,2 & \multirow{8}{*}{$\begin{array}{l}\text { Children with mild ID living } \\
\text { in their families }\end{array}$} \\
\hline & Fat & 4,6 & 3,3 & 5,1 & 2,5 & \\
\hline \multirow{3}{*}{ Boy $12-13$ age } & BMI & 21,2 & 21,0 & 22,9 & 22,2 & \\
\hline & Muscles & 22,3 & 25,1 & 29,7 & 31,1 & \\
\hline & Fat & 15,4 & 13,3 & 15,8 & 13,8 & \\
\hline \multirow{3}{*}{ Boy $14-15$ age } & BMI & 16,1 & 17,3 & 16,8 & 16,5 & \\
\hline & Muscles & 24,2 & 21,7 & 26,2 & 26,2 & \\
\hline & Fat & 3,9 & 7,0 & 4,2 & 3,6 & \\
\hline \multirow{3}{*}{ Boy $11-12$ age } & BMI & 23,4 & 23,6 & 24,6 & 25,4 & \multirow{6}{*}{$\begin{array}{l}\text { Children with moderate ID } \\
\text { living in their families }\end{array}$} \\
\hline & Muscles & 8,6 & 9,3 & 15,4 & 14,4 & \\
\hline & Fat & 20,3 & 23,7 & 18,0 & 21,1 & \\
\hline \multirow{3}{*}{ Girl 9-10 age } & BMI & 15,6 & 13,9 & 15,2 & 15,2 & \\
\hline & Muscles & 9,3 & 9,7 & 11,0 & 11,1 & \\
\hline & Fat & 6,0 & 4,3 & 6,1 & 6,1 & \\
\hline \multirow{3}{*}{ Boy $9-10$ age } & BMI & 18,2 & 19,6 & 18,5 & 19,1 & \multirow{9}{*}{$\begin{array}{l}\text { Children with mild ID living } \\
\text { in residential care }\end{array}$} \\
\hline & Muscles & 15,4 & 14,5 & 18,9 & 19,2 & \\
\hline & Fat & 8,1 & 11,8 & 8,2 & 10,4 & \\
\hline \multirow{3}{*}{ Boy 10-11 age } & BMI & 15,8 & 14,7 & 15,2 & 15,2 & \\
\hline & Muscles & 10,0 & 15,6 & 17,7 & 18,5 & \\
\hline & Fat & 14,3 & 5,3 & 5,3 & 5,7 & \\
\hline \multirow{3}{*}{ Girl 8-9 age } & BMI & 16,4 & 15,7 & 14,9 & 16,5 & \\
\hline & Muscles & 13,9 & 9,4 & 11,3 & 11,5 & \\
\hline & Fat & 2,7 & 3,3 & 3,6 & 3,9 & \\
\hline \multirow{3}{*}{ Girl $14-15$ age } & BMI & 19,1 & 17,7 & 20,4 & 21,8 & \multirow{9}{*}{$\begin{array}{l}\text { Children with moderate ID } \\
\text { living in residential care }\end{array}$} \\
\hline & Muscles & 19,4 & 19,3 & 18,1 & 18,5 & \\
\hline & Fat & 9,2 & 9,0 & 16,7 & 18,8 & \\
\hline \multirow{3}{*}{ Girl $11-12$ age } & BMI & 14,3 & 13,1 & 13,7 & 14,1 & \\
\hline & Muscles & 5,0 & 9,5 & 10,6 & 10,7 & \\
\hline & Fat & 11,6 & 2,7 & 3,5 & 4,4 & \\
\hline \multirow{3}{*}{ Boy 8-9 age } & BMI & 15,7 & 15,1 & 15,4 & 15,9 & \\
\hline & Muscles & 8,1 & 11,4 & 12,0 & 12,6 & \\
\hline & Fat & 8,8 & 7,9 & 10,2 & 4,5 & \\
\hline
\end{tabular}

To describe trends, Švancara's model for types of development was employed (Švancara, 1980, p. 20). For 3 to 4 subsequent measuring sessions only 4 types were used: stable, positive, negative and unstable (Válková, 1989).

BMI is an index of body weight which is commonly used to indicate underweight, normal weight and obesity. There are universal BMI ranges for the adult population which are not age- or gender-specific. However, there are no standardized ranges for children between the ages 5 and 
19. In children, BMI changes with sex and age. Based on the measured BMI value, one of five categories is allotted by age and sex. The categories are as follows obesity, overweight, normal, thinness and severe thinness. The child then can be assigned to one of these groups. BMI is defined as a person's weight in $\mathrm{kg}$ divided by the person's height in meters $\left(\mathrm{kg} / \mathrm{m}^{2}\right)$. The ratio is expressed by the following formula

$$
B M I=\frac{\text { weight in kilograms }}{(\text { height in metres })^{2}},(\text { WHO, 2018). }
$$

For dietary data collection a simple questionnaire of 5 questions to inquire about drinking and dietary habits was compiled. The method of communication during the data collection had been tried and tested in practise previously (Válková, 2014) and in the presented research included face-to-face communication with the children by means of pictures or samples of authentic foods. Teachers were available for support in case of need. In view of the children's cognitive capacity, the Likert scale was reduced to 3 options: "no", "sometimes", and "often". "Often" was evaluated as the most positive and assigned 3 points; "sometimes" was allotted 2 points and "never", indicating that the child never consumed the presented food, was ascribed 1 point. These options determine at what frequency the person consumes the food or drink The minimum score, i.e. the least healthy diet, amounted to 5 and the maximum, i.e. "the healthiest" diet, totalled 15 (Figure 2). Unsweetened drinks mean drinks without refined sugars.

The data collection was conducted in person and was repeated four times within space of 2 years as part of the entire survey. All 4 interviews were done by the same person who was well versed in the child's communication specifics and with whom the child was familiar.

Dependence between correlation and body composition was determined by correlation coefficient.

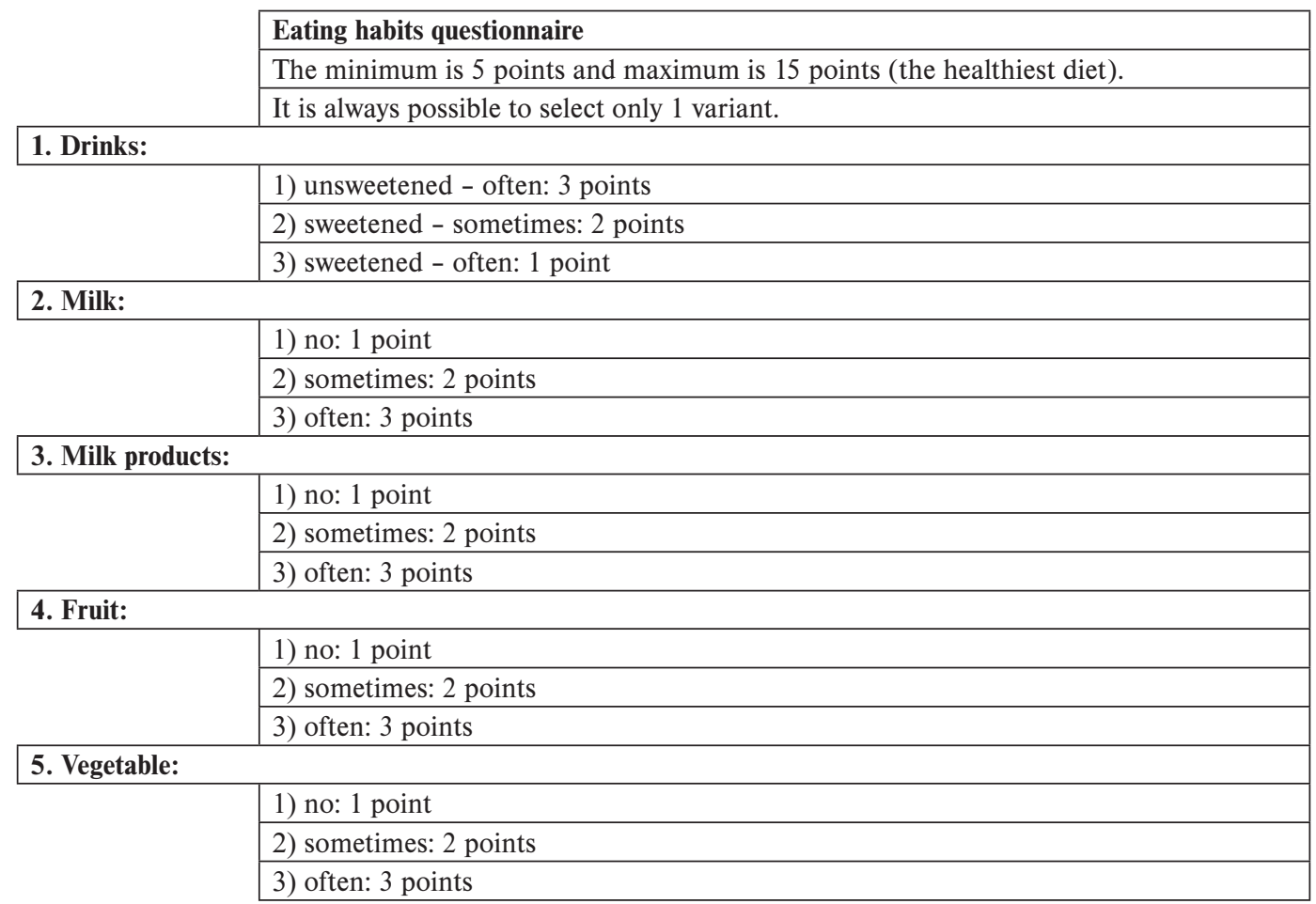

Fig. 2: Eating habits questionnaire

(Source: Healthy Community Project) 


\section{RESULTS}

\section{BMI trends among children living in their own home and residential care}

Figure 3 shows BMI trends among children with mild intellectual disability attending Otrokovice Primary School and living in their families. As can be seen, the weight of elderly boy and girl remained within norm, whereas the other boy was overweight for the whole research period.

One of the boys aged 12 to 13 and the girl tend to have a lower BMI following the period of the summer holiday (September 2017 and September 2018). The other boy aged 14 to 15 shows the similar tendency but with increase period of the summer holiday (September 2017).

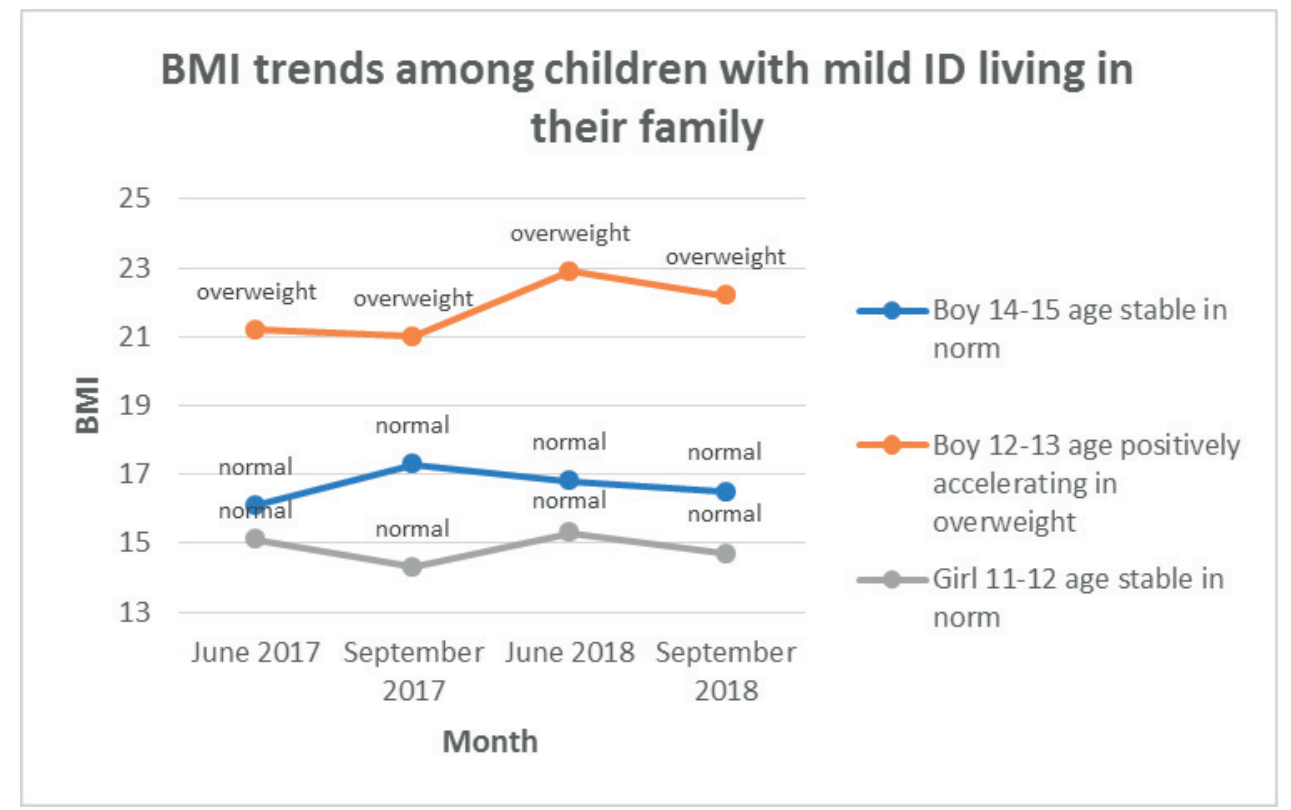

Fig. 3: BMI trends in children with mild intellectual disability attending Otrokovice Primary School

Figure 4 shows BMI trends among children with moderate intellectual disability attending Otrokovice Primary School and living in their families. As can be seen, the weight of both girls remained within norm, whereas the boy was obese for the whole research period.

One of the girls aged 13 to 14 tends to have a lower BMI following the period of the summer holiday (September 2017 and September 2018) and an increased BMI towards the end of the school year. The other girl aged 9 to 10 shows the same tendency. However, no changes in BMI were identified in 2018. The boy is associated with a continuous mild increase in weight. 


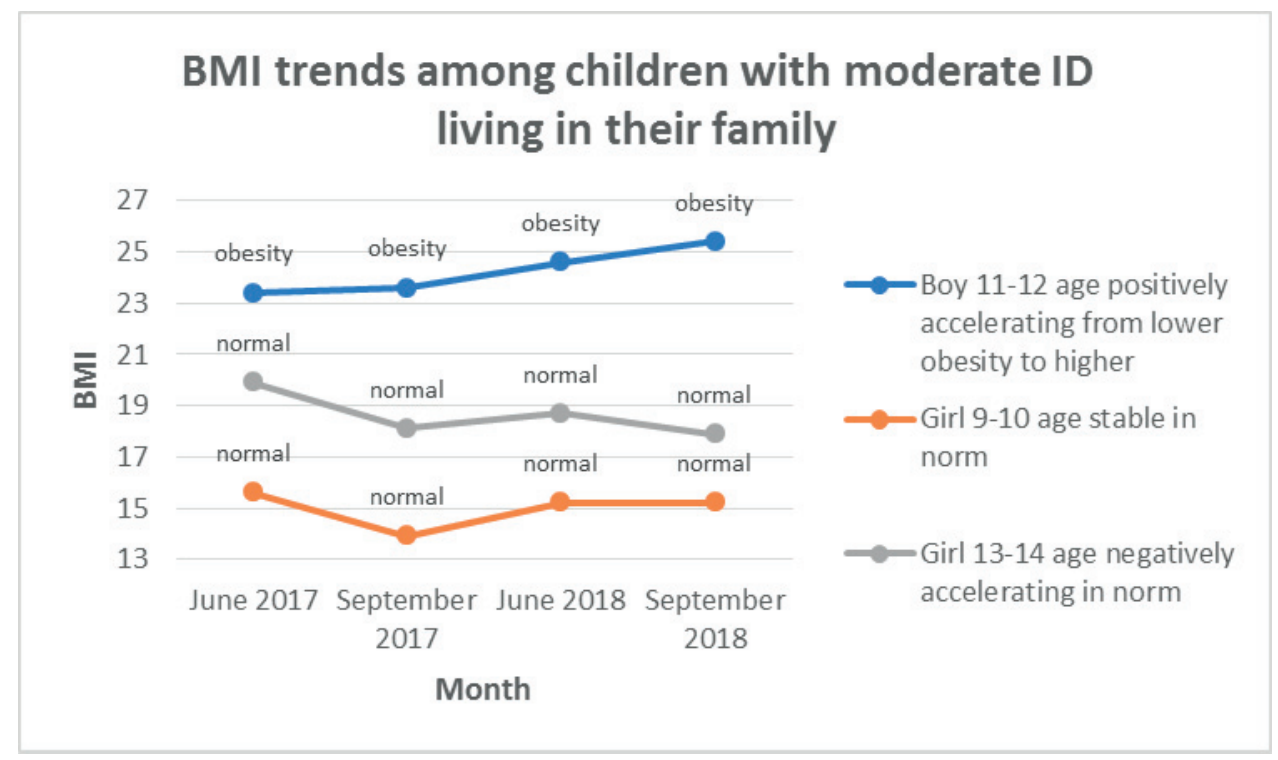

Fig. 4: BMI trends in children attending Otrokovice Primary School

Figure 5 demonstrates BMI trends in children with mild intellectual disability attending Zlín Primary School and living in a children's home. As can be seen, one of the boys aged 9 to 10 is overweight, whereas the other boy aged 10 to 11 and girl are in normal weight and do not show any change in weight during the whole research period.

It can be further concluded that all three children irrespective of their gender are associated with the same tendency which is apparent in a weight loss before the summer holiday (June 2018) and subsequently a mild weight gain after summer holiday (September 2018).

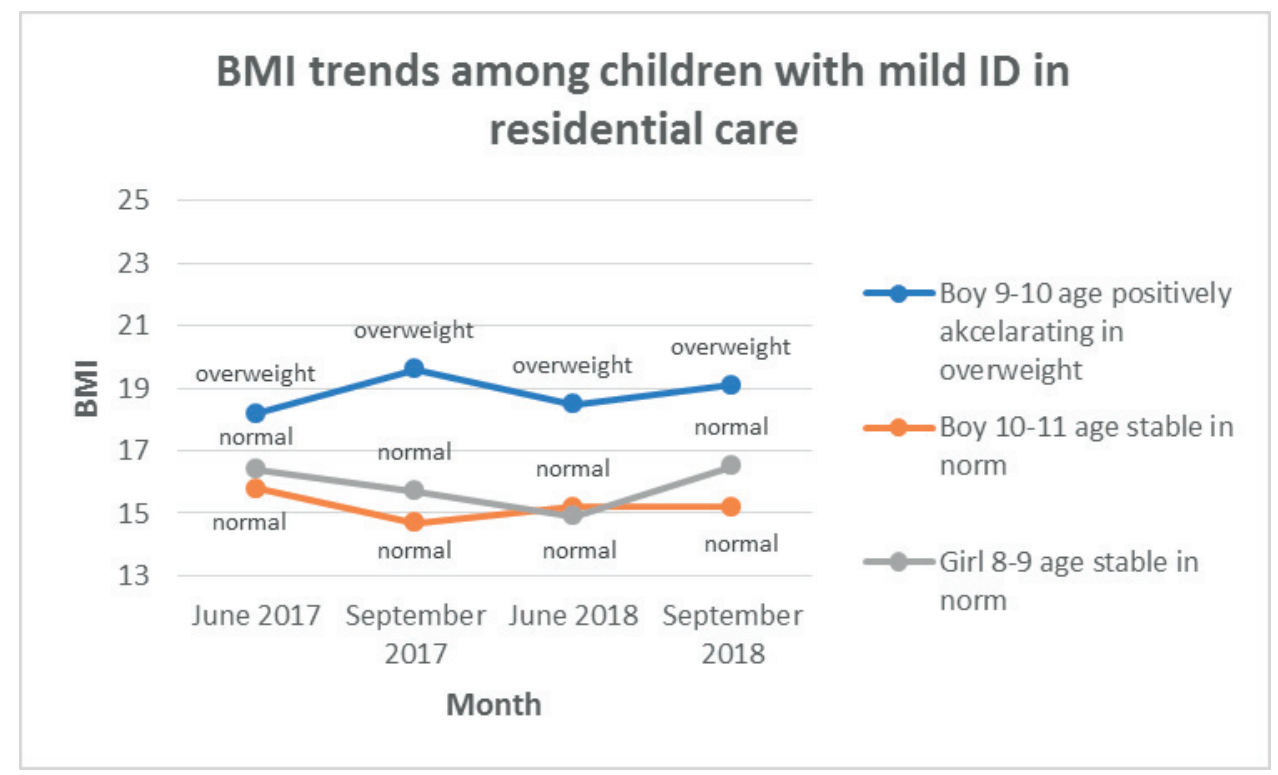

Fig. 5: Trends in children with mild intellectual disability attending Primary School Zlín 
Figure 6 demonstrates BMI trends in children with moderate intellectual disability attending Zlín Primary School and living in a children's home. As can be seen, one of the girls aged 11 to 12 is underweight, whereas the other aged 14 to 15 does not show any change in weight during the whole research period.

It can be further concluded that all three children irrespective of their gender are associated with the same tendency which is apparent in a weight loss following the summer holiday of 2017 and subsequently a continuous mild weight gain. Within the research period, the BMI of none of the respondents was affected by the summer holiday.

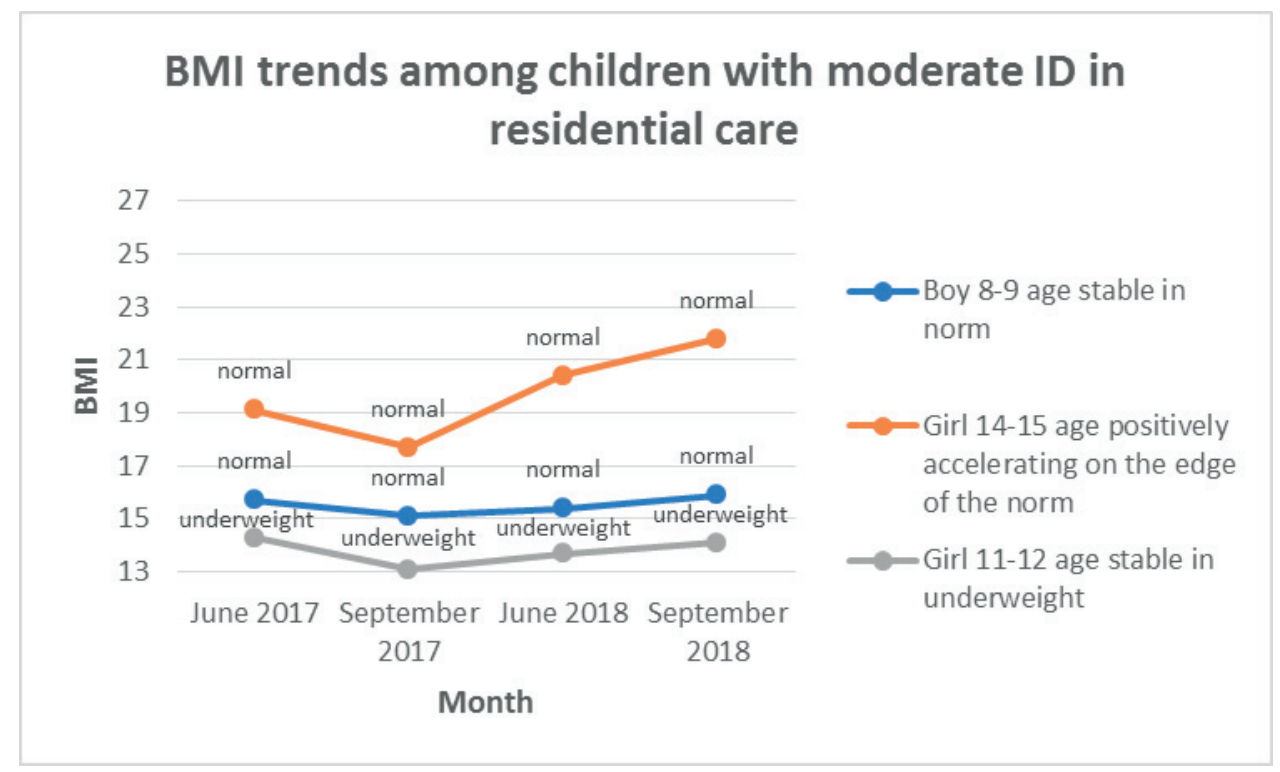

Fig. 6: Trends in children attending Primary School Zlín

\section{Dietary habits in children living in their own family and in a children's home}

By comparing questionnaire results of children living in their own home with mild ID and children with moderate ID (Table 3), it can be seen that children with moderate ID have better dietary habits by 0.17 points. The mean values among children with mild ID range between 9.25 and 12.50. The mean values among children with moderate ID vary between 10.25 and 12.75 out of the total score of 15 points.

Tab. 3: Dietary habits scores among children living in their own home

\begin{tabular}{|c|c|c|c|}
\hline $\begin{array}{c}\text { Children } \\
\text { with mild ID }\end{array}$ & $\begin{array}{c}\text { Average score } \\
\text { in questionnaire }\end{array}$ & $\begin{array}{c}\text { Children } \\
\text { with moderate ID }\end{array}$ & $\begin{array}{c}\text { Average score } \\
\text { in questionnaire }\end{array}$ \\
\hline Boy $14-15$ age & 9.25 & Boy 11-12 age & 10.25 \\
\hline Boy 12-13 age & 11.25 & Girl 9-10 age & 10.50 \\
\hline Girl 11-12 age & 12.50 & Girl 13-14 age & 12.75 \\
\hline All children & $\mathbf{1 1 . 0 0}$ & All children & $\mathbf{1 1 . 1 7}$ \\
\hline
\end{tabular}


By comparing questionnaire results of children living in in residential care with mild ID and children with moderate ID (Table 4), it can be seen that children with moderate ID have better dietary habits by 0.50 points. The mean values among children with mild ID range between 11.50 and 13.00. The mean values among children with moderate ID vary between 11.75 and 13.75 out of the total score of 15 points.

Tab. 4: Dietary habits scores among children living in residential care

\begin{tabular}{|c|c|c|c|}
\hline $\begin{array}{c}\text { Children } \\
\text { with mild ID }\end{array}$ & $\begin{array}{c}\text { Average score } \\
\text { in questionnaire }\end{array}$ & $\begin{array}{c}\text { Children } \\
\text { with moderate ID }\end{array}$ & $\begin{array}{c}\text { Average score } \\
\text { in questionnaire }\end{array}$ \\
\hline Boy 9-10 age & 12.25 & Girl 14-15 age & 11.75 \\
\hline Boy 10-11 age & 11.50 & Girl 11-12 age & 13.75 \\
\hline Girl 8-9 age & 13.00 & Boy 8-9 age & 12.75 \\
\hline All children & $\mathbf{1 2 . 2 5}$ & All children & $\mathbf{1 2 . 7 5}$ \\
\hline
\end{tabular}

By comparing dietary habits of children living in their own families and children living in a home in both categories ID (Table 5), it can be seen the diet of children in residential care is healthier by 1.25 points in mild ID and by 1.58 points in moderate ID. This difference is more significant than the difference within the same degree of ID.

Tab. 5: Dietary habits scores among children living in their own home and in residential care

\begin{tabular}{|l|c|c|}
\hline & Average score in questionnaire & Difference \\
\hline Children in family with mild ID & 11,00 & $\mathbf{1 , 2 5}$ \\
\hline Children in residential care with mild ID & 12,25 & \\
\cline { 1 - 2 } Children in family with moderate ID & 11,17 & $\mathbf{1 , 5 8}$ \\
\hline Children in residential care with moderate ID & 12,75 & \\
\hline
\end{tabular}

We can also see the healthiest diet have children with moderate ID living in residential care (12.75 points). The worst diet children have with mild ID living in their families (11.00 points).

\section{Correlation between eating habits and body composition}

The following table (Table 6) shows the correlation values. The direct mean correlation force is between dietary habits and muscles $(r=0,606)$ in children with moderate ID living in their family. The indirect mean correlation force is between dietary habits and fat $(r=-0,517)$ in children with moderate ID living in residential care. BMI has the closest dependence on the eating habits of children with moderate ID living in residential care $(r=0,253)$.

Tab. 6: Correlation between dietary habits and body composition

\begin{tabular}{|l|l|l|l|}
\hline Dietary habits & BMI & Muscles & Fat \\
\hline Children with mild ID in family & $\mathrm{r}=-0,115$ & $\mathrm{r}=0,293$ & $\mathrm{r}=0,225$ \\
\hline Children with moderate ID in family & $\mathrm{r}=-0,109$ & $\mathrm{r}=\mathbf{0 , 6 0 6}$ & $\mathrm{r}=-0,172$ \\
\hline Children with mild ID in residential care & $\mathrm{r}=-0,002$ & $\mathrm{r}=-0,129$ & $\mathrm{r}=-0,223$ \\
\hline Children with moderate ID in residential care & $\mathrm{r}=0,253$ & $\mathrm{r}=-0,191$ & $\mathrm{r}=-\mathbf{0 , 5 1 7}$ \\
\hline
\end{tabular}




\section{DISCUSSION}

Within the presented research, only one boy with Down syndrome, living in his own home, was obese. Melville, Hamilton, Miller \& Boyle (2007), who studied adult population, arrived at the same conclusion: people with Down syndrome are prone to obesity. Stancliffe et al. (2011) found out that there is a connection between obesity and living arrangements. There was a higher prevalence of obesity among people with ID living in their own home than in residential care. Within the presented research, this was confirmed in children with moderate ID living in their families. In children with mild ID living in the families, an overweight relationship was found.

It is noteworthy that prevalence of obesity among girls was not confirmed in any category. For instance, Hsieh, Rimmer \& Heller (2004) or Melville, Hamilton, Miller \& Boyle (2007) discovered a link between obesity and gender in adult population. Furthermore, many studies proved a connection between prevalence of obesity and intellectual disabilities in the adult population, for instance (Rimmer \& Yamaki, 2006), which was not true for the childhood population in our research. Eight out of twelve children have their BMI within norm, one child is underweight, two children are overweight, and only one child is obese. It is interesting that only boys are overweight and obese. It is highly likely that children with ID are physically more active than adults with ID. As a result, obesity is more prevalent in adulthood. All the research participants had the opportunity to attend one class of sports after-school activities in addition to the two weekly compulsory classes of Physical education as part of their school curricula. There is a wider range of after-school activities for children living in residential care.

One of the reasons may be the fact that children in residential care are attended by professionals, who are available for them in the children's free time and arrange various after-school activities for them, whereas children living in their own home depend on their parents' interest and free time. For instance, their parents may go cycling with them or drive them to an after-school sports club.

Furthermore, it is interesting to note that summer holiday (which in the Czech Republic are 2 months and children are at home during them) has effect on the BMI indicators in children living in their families and has little effect on the BMI indicators in children living in residential care as every child shows a different trend in peaks and falls in their BMI values. This is not true, however, for the year 2017 as the BMI indicator were higher in June 2017 in 9 out of 12 children than in September 2017. It may be safe to conclude that summer holiday meant more physical activity.

In 4 out of 6 children living in their families the BMI indicator were higher in June 2017 than in September 2017 and the BMI indicator were higher in June 2018 than in September 2018. It may be safe to conclude that summer holiday meant more physical activity than during the school year.

In 4 out of 6 children living in residential care the BMI indicator were higher in June 2017 than in September 2017, but the BMI indicator were lower in June 2018 than in September 2018. It may be safe to conclude that children have during summer holiday 2017 more physical activity than during the school year but that summer holiday 2018 meant less physical activity.

It is not surprising that children in residential care have a better diet than children living in their own home. Parents would have to pay more attention to their children's dietary needs and be instrumental in forming their children's healthy eating habits, i.e. offer more fruit and vegetables. Many parents do not feel comfortable refusing their children's cravings for sweets. This phenomenon can be linked to protectionist parenting and economic status. Children's diets in institutions, e.g. children's homes and schools, are subject to strict regulations. The staff are responsible for adhering to technological procedures and daily food portions in accordance with regulation No. 110/2005 Sb. on School Catering. There is also regular monitoring to ensure that these regulations are observed. Consequently, children in residential have a more limited choice within their dietary options. 


\section{CONCLUSION}

Research into BMI trends was conducted in space of two years in six children with mild ID and in six children with moderate ID at early school age and puberty. A half of these children lived in their own families and the other half in the Children's home in the Zlín region in the Czech Republic.

Only children with moderate ID living in their families are associated with obesity and tend to normal weight. Children with mild ID living in their family tend to overweight and normal weight. Children with mild ID living in residential care are not associated with obesity and tend to normal weight or overweight also children with moderate ID living in residential care are associated with normal weight or underweight. Obesity and overweight are connected only with boys.

Two thirds of children with mild ID and moderate ID living in their families follow the same pattern of BMI: a subsequent weight rise in June 2017 and 2018 but the holiday period is associated with a weight loss in September 2017 and 2018. Summer holiday influences the BMI indicators. Almost all children with mild ID and moderate ID living in residential care follow also the same pattern of BMI: the holiday period is associated with a weight loss in September 2017 and a subsequent weight rise in June 2018 which continues its upward trend in September 2018. There is no conclusive evidence that summer holiday influences the BMI indicators.

Children tend to remain in their BMI category, i.e. normal weight, underweight, overweight or obesity. No child manifested any changes in weight during the research period. With growing age, half of children have demonstrated a weight gain.

Children with moderate ID living in their families are provided a healthier diet than children with mild ID living in their families. As well as children with moderate ID living in residential care are provided a healthier diet than children with mild ID living in residential care. Children with mild ID and moderate ID in residential care are provided a healthier diet than children with mild ID and moderate ID living in their families, which means they consume fewer sweet drinks, more dairy products and fruit and vegetables.

The direct mean correlation force is between dietary habits and muscles in children with moderate ID living in their family. The indirect mean correlation force is between dietary habits and fat in children with moderate ID living in residential care.

It has been concluded that parents should consider arranging sports activities for their children provided they are not willing or able to do sport with them themselves. It would also be advisable to extend the range of sports activities in the vicinity of their homes and promote the importance of sport in children with ID. Parents are further recommended to pay more attention to their children's diets and prepare homemade food from healthy ingredients. More portions of fruit and vegetables should also be included in the diet. A workshop focusing on a healthy diet and food could be organised to increase parents' awareness in this area.

\section{Bibliography}

Bittles, A. H., Petterson, B. A., Sullivan, S. G., Hussain, R., Glasson, E. J., \& Montgomery, P. D. (2002). The influence of intellectual disability on life expectancy. The Journals of Gerontology, 57, 470-472.

Cooper, S. A., Melville, C., \& Morrison, J. (2004). People with intellectual disabilities. Journal of BMJ, 329, 414-415.

Duramy, B. F. (2018). Childhood obesity and positive obligations: a child rights-based approach. Journal of Seattle University Law, 42, 87-128.

Eurozprávy.cz (2018). Obézních dětí v Česku přibývá: za 20 let jich je dvakrát tolik. Retrieved from https://eurozpravy.cz/ domaci/spolecnost/235777-obeznich-deti-v-cesku-pribyva-za-20-let-jich-je-dvakrat-tolik/ (accessed May 19, 2019)

Havercamp, S. M., Scandline, D., \& Roth, M. (2004). Health disparities among adults with developmental disabilities, and adults not reporting disability in north Carolina. Journal of Public Health, 119, 418-426.

Hsieh, K., Rimmer, J. H., \& Heller, T. (2014). Obesity and associated factors in adults with intellectual disability. Journal of Intellect Disabilities, 58, 851-863. 
Kocourová, V. (2014). Mentální postižení. Retrieved from https://www.alfabet.cz/informace-o-typech-zdravotniho-postizeni/ mentalni-postizeni (accessed May 19, 2019)

Melville, C. A., Hamilton, S., Hankey, C.R., Miller, S., \& Boyle, S. (2007). The prevalence and determinations of obesity in adults with intellectual disabilities. Journal of Obesity, 8, 223-230.

NICM (2014). Klasifikace mentálního postižení. Retrieved from http://www.nicm.cz/klasifikace-mentalniho-postizeni (accessed May 19, 2019)

Patja, K., livanainen, M., Vesela, H., Oksanen, H., \& Ruoppila, I. (2000). Life expectancy of people with intellectual disability: a 35-year follow up study. Journal of Intellect Disabilities, 44, 591-599.

Rimmer, J. H., \& Yamaki, K. (2006). Obesity and intellectual disability. Journal of Mental Retardation and Developmental Disabilities Research Reviews, 12, 70-82.

Stancliffe, R. J., Lakin, K. C., Larson, S., Engler, J., Bershadsky, J., Taub, S. Fortune, J. \& Ticha, R. (2011). Overweight and obesity aboung adults with intellectual disabilities who use intellectual disability/developmental disability services in 20 U.S. The American Journal on Intellectual and Developmental Disabilities, 116, 401-418.

Studium Psychologie (2016). Etapy psychického vývoje: pubescence, adolescence. Retrieved from https://www.studiumpsychologie.cz/vyvojova-psychologie/6-pubescence-adolescence.html (accessed May 19, 2019)

Studium Psychologie (2016). Etapy psychického vývoje: vstup dítěte do školy, mladši školní věk. Retrieved from https://www. studium-psychologie.cz/vyvojova-psychologie/5-vstup-do-skoly-skola.html (accessed May 19, 2019)

Svačina, ̌̌., \& Bretšnajdrová, A. (2003). Cukrovka a obezita. Praha:T.A.V.A. Books.

Školní stravování, (2013). Vyhláška č. 107/2005 Sb. Retrieved from http://www.msmt.cz/vzdelavani/skolni-stravovani (accessed May 20, 2019)

Švancara, J. (in Švancara, 1980). Diagnostika psychického vývoje. Praha: Avicenum.

Švarcová, I. (2000). Mentální retardace: Vzdělávání, výchova, sociální péče. Praha: Portál.

Tanu, G., Manju, M., Rajesh, S., \& Vandana, J. (2018). Psychopathology and stress in Indian overweight and obese children: a case control study. Journal of Indian Association for Child, 14, 46-59.

Tyler, C. V., Schramm, S., Karafa, M., Tang A. S., \& Jain, A. (2010). Electronic Health Record analysis of the primary care of adults with intellectual and other developmental disabilities. Journal of Policy and Practice in Intellectual Disabilities, 3, $204-210$.

Vágnerová, M. (2004). Psychopatologie pro pomáhajicí profese (3rd rev. ed.). Praha: Portál.

Valenta, M., \& Müller, O. (2003). Psychopedie. Praha: Parta.

Válková, H. (2014). Special Olympics Healthy Athlete program: Concept and relation with HBSC study. Acta Universitatis Palackianae Olommucensis, Gymnica, 43, 46.

Válková, H. (2016). Zdravotně orientovaná zdatnost osob s mentálním postižením v programu Speciálních olympiád (přehled grantových projektů SO). Aplikované pohybové aktivity v teorii a praxi, 7, 44-52.

Válková, H., \& Krejčí, M. (in Švamberk Šauerová, 2016). Benefity využití sportovních a prožitkových aktivit v edukačních souvislostech. Praha: Palestra.

Válková, H., \& Thaiszová, V. (1989). A contribution to the motor abilities of mentally subnormal population. Acta Universitatis Palackianae Olommucensis, Gymnica, 19, 97-119.

WHO (2018). Body mass index - BMI. Retrieved from http://www.euro.who.int/en/health-topics/disease-prevention/ nutrition/a-healthy-lifestyle/body-mass-index-bmi (accessed May 20, 2019) 